Костусяк, Наталія, і Приймачок, Оксана. «Текстові лакуни міжслов'янського художнього перекладу в аспекті міжкультурної комунікації». Лінгвостилістичні студії, вип. 11, 2019, с. 65-78.

Kostusiak, Natalia, and Pryimachok, Oksana. "Text Lacunae in Inter-Slavic Literary Translation: Intercultural Communication Aspect". Linguostylistic Studies, iss. 11, 2019, pp. 65-78.

УдК [82.0:811.16'255.4]:[130.2:316.77]

https://doi.org/10.29038/2413-0923-2019-11-65-78

\title{
ТЕКСТОВІ ЛАКУНИ МІЖСЛОВ'ЯНСЬКОГО ХУДОЖНЬОГО ПЕРЕКЛАДУ В АСПЕКТІ МІЖКУЛЬТУРНОЇ КОМУНІКАЦІЇ
}

\author{
Наталія Костусяк, Оксана Приймачок \\ Східноєвропейський національний університет імені Лесі Українки, \\ Луцьк, Україна
}

У статті виокремлено, класифіковано й описано текстові лакуни (культурологічні та власне мовні), що виникли в процесі міжслов'янського художнього перекладу як особливого різновиду міжкультурної комунікації. Матеріалом дослідження став роман М. Стельмаха «Чотири броди» та його переклад російською мовою. Встановлено, що лакуни етнокультурного плану найчастіше спричинені національно-специфічними реаліями, словами-символами, ономастичною лексикою, прецедентними образами українського фольклору і літератури. Власне мовні лакуни виникають при перекладі слів певних словотвірних чи граматичних класів, авторських новотворів, емоційно-оцінної лексики. Досліджено основні способи елімінування лакун, водночас наголошено на некомпенсованих лакунах у російському перекладі.

Ключові слова: лакуна, міжкультурна комунікація, художній переклад, близькоспоріднені слов'янські мови, елімінування лакун.

\section{TEXT LACUNAE IN INTER-SLAVIC LITERARY TRANSLATION: INTERCULTURAL COMMUNICATION ASPECT Natalia Kostusiak, Oksana Pryimachok \\ Lesya Ukrainka Eastern European National University, Lutsk, Ukraine}

In recent years, researchers in the field of lexical systemology, cognitive, contrastive, and translational linguistics, intercultural communication have become increasingly interested in the issues of lacunarity. The concept of lacuna has transformed its content from the phenomena when a word of one language has no equivalent in another language (narrow understanding) to complex gaps in the interlingual and intercultural communication due to the national-specific features of culture and specific linguistic pictures of the communicants' world (broad understanding of lacunae). Literary translation is a specific intercultural communicative situation. Mykhailo Stelmakh's novel "Four Fords" and its translation into Russian is the case study for revealing lacunae and the ways of their elimination. Since an artistic text is a kind of a peculiar culturological model, which represents nationally specific features of verbal and nonverbal behavior of an ethnic group, the study of this text from the standpoint of lacunarity theory will enable its ethnic-psycholinguistic interpretation and optimize intercultural dialogue. What does not coincide in these languages and cultures requires interpretation, commenting, search for non-standard strategies for combining images of "one's own" and "foreign" in order not only to understand but also to perceive the

(c) Костусяк Н., Приймачок О., Східноєвропейський національний університет імені Лесі Українки, 2019.

Це стаття відкритого доступу на умовах СC BY-NC 4.0 
aesthetic charge of the original in the translator's version adequately. All text lacunae, identified while comparing the original and the translation, tentatively fall into the categories of culturological and linguistic ones. The lacunae of the ethnocultural nature occur in case of national-specific realities, word-symbols, proper names, or precedent images of the Ukrainian folklore and literature. Linguistic gaps arise when a translator attempts to convey in target language words of some word-forming models or grammatical categories, author's neologisms, emotional and evaluative vocabulary. The typological and genealogical similarity of the Slavic languages promotes transliteration as the most popular way of eliminating gaps, which may be accompanied by textual or line commentaries. A common practice is a descriptive way of interpreting non-equivalents or their lexical replacement (by a hyponym, hyperonym, or analogue). However, uncompensated gaps or translation losses are inevitable, even when the differences appear in similar linguistic pictures of the world.

Key words: lacuna, intercultural communication, literary translation, closely related Slavic languages, elimination of lacunae.

Вступ. Сучасне мовознавство марковане тенденцією до інтеграції парадигм, що розширює усталені уявлення про функції та потенції мовних одиниць. Сформований протягом довгої історї̈ лінгвістичних студій комплексний підхід до вивчення мови значною мірою зумовив погляди на останню як на відображення особливостей менталітету нації, повноцінне джерело етнокультурного коду, а не тільки інструмент спілкування i пізнання. Згадана множинність функціоналу мови полягає у ї̈ одночасному існуванні у вербальній та екстралінгвальній іпостасях, які інкорпорують світосприйняття носіїв. Лінгвістичні концепції XX-XXI ст. приділяють увагу взаємозв'язку мовних і культурних феноменів, що втілено у класичних публікаціях В. фон Гумбольдта, Е. Сепіра, Б. Уорфа, О. Потебні та ін. Сучасні дослідження в галузі лексичної системології, когнітивної, контрастивної і транслятивної лінгвістики, міжкультурної комунікації свідчать про неабияку зацікавленість проблемами лакунарності. 3'явившись у науковому обігу в середині ХХст., поняття лакуни трансформувалося від явища, коли слово однієї мови не має відповідника в іншій мові (у концепції канадських перекладознавців Ж.-П. Віне, Ж. Дарбельне), до цілого комплексу прогалин міжмовного та міжкультурного спілкування, зумовлених національно-специфічними компонентами культури й особливими мовними картинами світу комунікантів. Таке різне (вузьке й широке) потрактування лакун $\epsilon$ результатом переосмислення однієї з фундаментальних проблем мовознавства - співвідношення мови і мислення: жорсткого зв'язку між поняттям і мовною формою його втілення не існує; поняття не завжди вербалізоване, воно може існувати в національній культурі імпліцитно, адже «мова фіксує далеко не все, що є в національному баченні світу, але здатна описати все» (Тер-Минасова 48).

Багатоаспектне поняття лакуни, застосовуючись у сучасних наукових парадигмах, виявляє різні свої грані та сприяє розв'язанню проблем теоретичного й прикладного характеру. Так, когнітивна лінгвістика, вивчаючи мовну картину світу як результат пізнавальної діяльності людини, оперує поняттям лакуни, аби закцентувати на оригінальності i 
неповторності кожної такої мовної картини. Етнопсихолінгвістика, вивчаючи мовно-поведінкові стереотипи представників різних соціокультурних спільнот, лакунами називає такі особливості, які не мають аналогів і тому можуть сприйматися як дещо дивне, незрозуміле чи навіть неправильне. Зіставне мовознавство і лінгвістична типологія, прагнучи встановити мовні універсалії та унікалії на шкалі подібне / відмінне в мовах, базується на принципі: «Немає мов, які б не мали спільних ознак зі всіма іншими мовами, але немає й мов, які б не мали власних, властивих тільки їм рис» (Кочерган 55). Оці унікальні риси й будуть лакунарними щодо інших мов.

Лінгвістичний аспект міжкультурної комунікації, який «не обмежується виявленням семантичних особливостей слів різних мов, <..>> охоплює зіставлення різних комунікативних ситуацій, способи членування світу мовними засобами, порівняння мовної поведінки представників різних культур» (Манакін 13), передбачає особливу увагу до вербальних лакун, оскільки саме вони можуть спричинити проблеми у спілкуванні різними мовами (наприклад, у процесі перекладу).

Мета дослідження. Специфіка міжслов'янського перекладу, який здійснюється в межах близькоспоріднених мов, полягає в тому, що на тлі генетично спільного чи подібного («свого») треба виявити відмінне («чуже») й органічно пристосувати його до нових умов існування. Тому основною метою цієї статті $\epsilon$ пошук лакун як для виявлення й опису етнокультурної інформації оригіналу, що спричинила їх появу, так і для вирішення окремих проблем перекладознавства та міжкультурної комунікації (способи елімінування лакун).

Матеріал і методи дослідження. Джерельною базою роботи став текст роману М. Стельмаха «Чотири броди» та його переклад російською мовою, здійснений Н. Андрієвською. Основні методи дослідження: порівняльно-перекладознавчий (для аналізу паралельних текстів оригіналу і перекладу - і виявлення лакун), зіставно-типологічний (для кваліфікації лакунарних явищ), лінгвостилістичний (для визначення художньо-естетичної цінності безеквівалентів та можливих способів і прийомів елімінування лакун).

Результати дослідження і дискусія. 3 поняттям лакуни найтісніше пов'язані (але не тотожні) такі поняття, як безеквівалентна лексика, реалія, етнолексема, лінгвокультурема, екзотизм, фонова лексика тощо. Ці терміни так часто вживають у межах одного дослідження, що іноді навіть синонімізують (див., наприклад, Кочерган 326-327). Однак насправді вони пов'язані не синонімічними, а причинно-наслідковими відношеннями: лакуна (прогалина) в одній мові виникає саме тому, що неможливо підібрати однослівний відповідник до конкретного слова іншої мови. 3 позицій лінгвістичної системології можливі три основні типи лексичних відповідників: лінійні, коли одній лексемі мови 1 відповідає одна лексема мови 2 (наприклад, рос. рука - укр. рука), векторні, коли одному слову мови 
1 відповідає кілька слів мови 2 (рос. область - укр. область, край, ділянка, галузь) і лакунарні, коли до слова мови 1 неможливо знайти словоеквівалент у мові 2 (укр. різка - рос. срезанная ветка, укр. правиця - рос. правая рука) (Быкова).

3 появою досліджень В. Жельвіс, І. Марковіної і Ю. Сорокіна поняття лакунарності поширюється не тільки на мовні (мовленнєві) явища, а й на позамовні кореляти: «лакуни - це «білі плями» (за визначенням Ю. Степанова) на семантичній карті мови, тексту чи культури, що $€$ способом існування національної свідомості» (Марковина, и Сорокин 4).

3 тих пір «класифікаційна сітка лакун» (Марковина, и Сорокин) має приблизно такий вигляд. 3 одного боку, лакуни поділяють на мовні та культурологічні (соціокультурні). 3 урахуванням різних чинників, мовні лакуни бувають лексичними, граматичними й стилістичними; абсолютними (повними) і відносними (частковими). Культурологічні лакуни, своєю чергою, поділяють на етнографічні, психологічні, етикетні, кінестетичні. 3 іншого боку, і мовні, і культурологічні лакуни бувають інтер- (мовні, культурні) та інтра- (мовні, культурні); імпліцитні та експліцитні; контрастивні та конфронтативні (Колода 116). Зацікавлення лакунами настільки жваве, що цілком очікувані нові аспекти і характеристики, тим паче при широкому потрактуванні феномену лакунарності з проєкцією на завершене художнє ціле (текст) як об’єкт міжкультурної комунікації.

Особливою ситуацією міжкультурного спілкування $€$ художній переклад. Оскільки художній текст - це модель певного культурологічного фрагменту, в якому зафіксовано національно-специфічні особливості вербальної й невербальної поведінки певного етносу, то дослідження цього тексту з позицій теорії лакунарності (а для цього конче потрібен зіставний аспект: мова оригіналу - мова перекладу) уможливить його етнопсихолінгвістичне потрактування й оптимізує міжкультурний діалог. Саме те, що не збігається в цих мовах і культурах, потребує інтерпретації, коментування, пошуку нестандартних стратегій поєднання образів «свого» і «чужого», аби не лише зрозуміти, а й адекватно сприйняти естетичний заряд першотвору у версії перекладача.

У зіставній лексикології існування лакун (у найвужчому їх розумінні) пояснюють «різними способами передавання (ономасіологічний аспект) спільних для різних мов концептів. У цьому випадку йдеться про закономірності аналітизму й синтетизму лексичної номінації» (Манакин 147). Інакше кажучи, те, що в одній мові названо одним словом, може мати відповідники в інших мовах, проте ці відповідники не однослівні, наприклад: укр. залізниця - рос. железная дорога; укр. дочитати - англ. to read to the end.

Найчастіше у російській версії «Чотирьох бродів» лакуни культурного плану спричинені лексемами розмовно-побутового стилю, історизмами та архаїзмами. Це слова, які позначають національно- 
культурні реалії українського народу. Найповніше визначення цього поняття дала Р. Зорівчак: «Реалії - це моно- і полілексемні одиниці, семантична структура яких уміщає (у плані бінарного зіставлення) традиційно закріплений за ними комплекс етнокультурної інформації, чужої для об'єктивної дійсності мови-сприймача в певний історичний момент» (58).

у близькоспорідненому перекладі найпоширенішим способом передавання реалій $\epsilon$ транслітерація, тобто намагання все-таки одним словом (нехай навіть іншомовним) заповнити лакуну. Перекладачі розраховують на схожість слов'янських мов, на спільнослов'янський лексичний фонд, на певні моменти спільної культури чи історії, які зрештою полегшать сприйняття не зовсім знайомих читачам понять. Наприклад: ...нарешті діждалися гетьманської корогви, булави й бунчука (Стельмах, Чотири 144) - ...наконец дождались гетманской хоругви, булавы и бунчука (Стельмах, Четыре 117); Лісник вивинув із свитки скриньку... (Стельмах, Чотири 89) - Лесник освободил от свитки сундучок (Стельмах, Четыре 70); Гримич здійняв зі стіни аж чорну від старості кобзу, провів руками по струнах... (Стельмах, Чотири 214) - Гримич снял со стены почерневшую от времени кобзу... (Стельмах, Четыре 176); Всем могуществом нашей немецкой энергии мы раз и навсегда должны заглушить бандуру Шевченко (Стельмах, Четыре 418); Данило увидел, что из-под подушки торчит уголок какой-то книги. Это были украинские думы (Стельмах, Четыре 202).

Однак ціла низка транслітерованих історичних i побутових українських реалій, прецедентних власних назв може викликати серйозні проблеми для читача, бо формально такі лакуни еліміновані, але семантично порожні: Может, заглянуть в школу, к тому человеку, который так похож на казака Голоту? (Стельмах, Четыре 216); опришки! Ветрогоны! - прикрикнула на них сестра (Стельмах, Четыре 147); Было ж у нас преславное Запорожье (Стельмах, Четыре 63); И в седине веков старик видел Морозенко, из которого враги живьём вырвали сердце... (Стельмах, Четыре 176); А люди отдыхают себе, потому что коротка ночка-петровочка... (Стельмах, Четыре 143); Вечер добрый! Не прогоните примака? (Стельмах, Четыре 48); Мы до сих пор ни по ком не сохли, вот и прилипло к нам «старые парубки» (Стельмах, Четыре 346); Миколка перебирал стебли пшеницы, лепетал, что Владимир сплетёт ему из них брыль (Стельмах, Четыре 30); У вас, дядько, не серчайте, я наймитом стану подъяремным (Стельмах, Четыре 32); Радовался встрече с тем дивом, которого ждал годами то из грустных чар веснянок... (Стельмах, Четыре 162), ...Из высокой клуни выглянул Стёпочка (Стельмах, Четыре 71). У цьому разі можна говорити про імпліцитні лакуни як про перекладацькі втрати, бо при збереженні іншомовної одиниці в тексті перекладачі не потурбувалися про іï семантичне наповнення для реципієнта. 
Тому значна частина транслітерованих реалій чи прецедентних власних назв потребує різноманітних адаптацій, як-от: короткого коментування, додавання, пошуку аналогів, адекватних замін тощо. В аналізованому творі перекладач зрідка вдається до підрядкових (у виносках) приміток, наприклад: Кто бы это мог быть? Полевая царевна, которую встретил когда-то Чипка весной? [прим. Чипка - герой романа Панаса Мирного «Потерянная сила»] (Стельмах, Четыре 111); А почему вы такие грустные да невесёлые, словно сотник Забрёха? - вспомнил кладовщик классику [прим. Сотник Забрёха - персонаж из повести Г. Квитки-Основьяненко «Конотопская ведьма»] (Стельмах, Четыре 424); Такому, видать, сам Гнатко Беспятко из пекла не угодит [прим. Гнатко Беспятко - чёрт, персонаж украинского фольклора] (Стельмах, Четыре 296). Перекладацький коментар з'являється i тоді, коли транслітерація вимушена, бо вона підтримує римо-ритмічні особливості чи гру слів оригіналу: За татарским бродом поблизости от присёлка голосисто отозвался молодой погоныш: «Крыйок-крок, крыйок-крок!»... Птенец делает свои первые шаги в жизни [прим. Крок - шаг] (Стельмах, Четыре 4); - Садись назад, да не сломай насад, - пошутил лесник [прим. Насад - часть телеги] (Стельмах, Четыре 99); Пока у бабы спекутся кныши, у деда не станет души [прим. Кныши - калачи] (Стельмах, Четыре 142); Я молочко жать не буду, у меня корова даёт молочко [прим. Молочко - зерно молочной спелости] (Стельмах, Четыре 132).

Коментарі (примітки) перекладача чи редактора - це різновид додавання до оригінального тексту певної інформації з метою подолання можливих лакун (детальніше про це див. Приймачок). В окремих випадках таке додавання може з'явитися і в самому перекладі. Наприклад: Семен згадав дивака пана, який ... стягував на подвір'я половецьких та скіфських баб (Стельмах, Чотири 302) - Семён вспомнил чудаковатого помещика, который ... свозил в усадьбу половецких и скифских каменных баб (Стельмах, Четыре 248); Оце ж деякі, дуже кебетні, назвали нашого хлібороба хитрим дядьком (Стельмах, Чотири 377) - Вот же некоторые, слишком мудрые, назвали нашего украинского хлебороба "хитрым дядькой» (Стельмах, Четыре 310); - Не смійся, батьку! - як Остап 3 славнозвісного твору, відрізав Лимаренко (Стельмах, Чотири 491) - Не смейся, батько! - как Остап в прославленном произведении Гоголя бросил Лимаренко (Стельмах, Четыре 396).

Особливим різновидом безеквівалентної лексики $є$ також слова, що збігаються у двох мовах своїми денотатами (тобто об'єктивним змістом), але різняться своїми конотатами (тобто емоційно-естетичними асоціаціями). Насамперед ідеться про фольклорні образи-символи, що мають яскраву національну специфіку, сформовані на основі конкретної лексики на позначення реалій близької до людини природи. Саме такі «приховані» семи можуть спричинити в перекладі лакуни культурного простору. 
В українській етнокультурі верба займає значне місце: з неї здавна виготовляли музичні інструменти; під цим весняним деревом водили круглий танець і співали веснянок, вербове гілля освячували перед Великоднем, бо вважалося, що верба відганяє від людини злих духів і хвороби. Верба була і $\epsilon$ окрасою українського села і вказувала на життєдайну воду (де верба, там вода; там криниця, де вербищя) (Жайворонок 72-74). Калина в світосприйманні українців стала символом краси, любові, плодючості, пам'яті, буяння, цнотливості і навіть самої України (Без верби й калини немає України). Цей полісемантичний символ широко представлений у багатьох українських обрядах, прислів'ях, приказках, загадках, порівняннях (Жайворонок 269-270): Наприклад: Верби стояли над бродом, як жінки у прощанні, і плакали теж, мов жінки. $A$ може, вони й були колись жінками? 3 дівочої вроди виросла калина, то могла і верба зрости з материнського болю... (Стельмах, Чотири 506). У російському перекладі до цих та багатьох інших назв (євшан-зілля, дуб, квітка папороті, полин, перекотиполе, рута, ряст) підібрано їхні точні еквіваленти, хоча загальновідомо, що лише в мовній свідомості українців ці фітоніми опоетизовані, пов'язані 3 певними символами, тоді як їх російські паралелі позбавлені такої образності. Такі специфічні мовні знаки, на жаль, можна компенсувати тільки поверхнево, на денотативному рівні, прагматичний свій потенціал вони втрачають, тобто стають у певному сенсі лакунами. Цікаво, що слова-символи, пов'язані з чоловічими образами, мають і граматичну категорію чоловічого роду (дуб, явір, орел, сокіл), а ті, що стосуються жінок, - відповідно жіночого роду. Наприклад: $I$ дівчат із серпами примітив. Не дівчата - тополі - Не одна тепер у самоті тополею стане, бо переб'ють нашого брата за цю прокляту війну (Стельмах, Чотири 408). Численні українські перекази свідчать про віру людей у трагічне перевтілення дівчини в тополю, тому до семи 'струнка, тонка, гнучка' додається сема смутку через нещасливе кохання чи розлуку. Російський еквівалент чоловічого роду тополь жодним чином не пов'язаний ні $з$ дівочою зовнішністю, ні $з$ жіночою долею: И девчат $c$ серпами приметил. Не девчата - топольки. - Не одна теперь в одиночестве станет тополем, когда перебьют нашего брата в этой проклятой войне (Стельмах, Четыре 330). Некомпенсована лакуна очевидна.

Особливо знаковим став у романі «Чотири броди» ключовий образ броду - «символ тернистого шляху, набуття людиною знань, досвіду, символ невідомого, часто небезпечного життєвого вибору» (Жайворонок 56). Поетичний образ чотирьох бродів виникає відразу на початку роману (цитата з народної пісні Розлилися води на чотири броди... (Стельмах, Чотири 7)) і дає назву цілому твору М. Стельмаха. У романі, як і в його перекладі, лексема брід/брод вживається головно в своєму прямому значенні: Ось і його річка, що має чотири броди, ось і принишкле село з корогвами тополь, ось і його могутні ясени над стемнілим плотом, $i$ 
старенькі вдовині ворітия... (Стельмах, Чотири 7). Символіка цієї лексеми стає зрозумілішою для російського читача після перекладу репліки одного з героїв роману: А вот есть иные у человека броды: голубой, как рассвет, детства, потом, словно сон, - хмельной брод любви, затем - безмерного труда и забот и, наконец, - внуков и прощания. Мой дед, бывало, говорил: по четырём бродам текут воды жизни, а назад не возвращаются... (Стельмах, Четыре 86). Текстотвірний символ декодовано, потенційну лакуну еліміновано.

I культурологічні, і мовні лакуни художнього перекладу можуть бути еліміновані описовим способом, який непомітно для читача двома-трьома словами дозволяє передати точне значення безеквівалента (i реалії, i емоційно-забарвленої лексики, й оказіоналізмів, і граматично зумовлених моментів). Наприклад: Його веселе око все прицілювалося то до печі, то до мисника (Стельмах, Чотири 11) - Его весёлый глаз так и прищеливался то к печи, то к полке с посудой (Стельмах, Четыре 8); У неї навіть вівсяник місяцем сяє (Стельмах, Чотири 12) - У неё овсяный корж и тот, как месяи, светит (Стельмах, Четыре 9); А син приїжджав на хутір, щоб набрати садовини, сушні чи меду на потаємний продаж (Стельмах, Чотири 23) - А сын приезжал на хутор набрать для тайной продажи сушёных фруктов, мёду (Стельмах, Четыре 17); Шелест житнього снопа на покутті, якому снилася свіжа рілля... (Стельмах, Чотири 23) - И в красном углу шорох ржаного снопа, которому снилась свежая борозда... (Стельмах, Четыре 18); Весіллям, перезвою, любощами треба виганяти журбу, бо інакше і вік піде за водою та сльозою (Стельмах, Чотири 35) Свадьбой, весельем, любовными утехами надо прогонять тоску... (Стельмах, Четыре 27); Може, Оксано, якогось ощіпка спечеш? Ось приніс вам борошна (Стельмах, Чотири 62) - Может, Оксана, пресный корж испечёшь? Муку я принёс... (Стельмах, Четыре 49); Гарну матиму вербницю! (Стельмах, Чотири 92) - Хорошая будет у меня вербная неделя! (Стельмах, Четыре 73); Ох, це осіннє гайвороння згадок! (Стельмах, Чотири 125) - Ох, уж эта осенняя воронья стая воспоминаний! (Стельмах, Четыре 101); Це дужень, а не старець (Стельмах, Чотири 119) - Это дюжий мужик, а не хилый нищий (Стельмах, Четыре 95); Лише молодика бракує над ними (Стельмах, Чотири 320) - Лишь молодого месяща не хватает над ними (Стельмах, Четыре 264); Найкраще було б, якби ти дав діжу з розчиною (Стельмах, Чотири 451) - Лучше всего было бы, если бы ты дал квашню с закваской для теста (Стельмах, Четыре 362); Нарік ця сама качка прилетить із вирію на цей самий ставок (Стельмах, Чотири 493) - Через год эта утка прилетит из дальних тёплых стран на этот самый ставок (Стельмах, Четыре 397); $A$ ви подумали, яка про мене завтра неслава піде? (Стельмах, Чотири 544) - $A$ вы подумали, какая обо мне завтра дурная слава пойдёт? (Стельмах, Четыре 440); А як гарно на дівчині зацвітають тернова хустка і червоний кожушок! (Стельмах, Чотири 588) - А как красиво на девушке расцветает 
чёрный, в ярких красках платок и красный кожушок! (Стельмах, Четыре 477).

У досліджуваних текстах спостережено кілька різновидів мовних лакун, спричинених, наприклад, оригінальними українськими похідними прислівниками, які російською можна перекласти тільки описово: Напровесні Данило почув, що Магазаник по шкуродерних цінах продає хліб (Стельмах, Чотири 88) - Ранней весной Данило прослышал, что Магазанник по шкуродёрным ценам продаёт хлеб (Стельмах, Четыре 70); Збирайте попідтинню даяння $i$ не дуріть нам голови (Стельмах, Чотири 147) - Собирайте под заборами подаяние и не дурите нам голову (Стельмах, Четыре 120); Чорнозем із зіллям полетів навсібіч, оголюючи металеве тіло (Стельмах, Чотири 87) - Чернозём с травой полетел во все стороны, обнажая металлическое тело (Стельмах, Четыре 392); Свого поїзда партизани дочекалися тільки вдосвіта (Стельмах, Чотири 571) Своего поезда партизаны дождались только на рассвете (Стельмах, Четыре 463); Тоді в зіниці їі заскакувала така циганська гострота, що й одчайдухам було непереливки (Стельмах, Чотири 543) - Тогда в её глазах сверкала такая цыганская ярость, что и самым отчаянным становилось не по себе (Стельмах, Четыре 439); Нарік ця сама качка прилетить із вирію на цей самий ставок (Стельмах, Чотири 493) - Через год эта утка прилетит из дальних тёплых стран на этот самый ставок (Стельмах, Четыре 397).

Так звані граматичні (випадкові) лакуни поодинокі і пов'язані 3 неможливістю синтетично передати якусь граматичну чи словотвірну модель або форму. В українському розмовному мовленні, наприклад, частіше вживається проста форма суперлатива: Сподівався: ціна підійметься на найвищий гребінь... (Стельмах, Чотири 88) - Надеялся на то, что цена поднимется на самый высокий уровень... (Стельмах, Четыре 70), а суфікси суб'єктивної оцінки вживаються значно ширше, ніж в інших слов'янських мовах: Невже чудо? - справжнісіньке! (Стельмах, Чотири 86) - Неужели чудо? - Самое настоящее! (Стельмах, Четыре 69).

Власне мовних лакун чимало й серед дієслів, особливо конкретної словотвірної моделі. Наприклад, в українській мові досить регулярними $\epsilon$ відіменникові дієслова зі словотвірним значенням «займатися чим-небудь певний час», утворені переважно суфіксальним способом за допомогою форманта -ува-: вчителювати, слюсарювати, парубкувати, пасічникувати тощо. У досліджуваному російському перекладі така словотвірна модель виявилася лакунарною: Сам кошовий Іван Сірко на старості недалеко від Січі пасічникував (Стельмах, Чотири 28) - Сам кошевой Иван Сирко на старости недалеко от Сечи был пасечником (Стельмах, Четыре 22); Спочатку він (березень) парубкує по лісах... (Стельмах, Чотири 45) Сначала гонец весны привольно гуляет по лесам (Стельмах, Четыре 35); Хто ж це такий нетерплячий першим вийшов жнивувати? (Стельмах, Чотири 236) - Кто же это такой нетерпеливый первым вышел на 
жатву? (II, с. 196); Все життя чабанували в степах (Стельмах, Чотири 349) - Всю жизнь провели чабанами в степях (Стельмах, Четыре 288); I досі пам'ятаю її голос - вона ж із моєю Ганею дівувала (Стельмах, Чотири 473) - До сих пор помню её голос - она же с моей Ганной была в девушках (Стельмах, Четыре 383); Звернули до оселі отця Бориса, який із піввіку попував на одному місці (Стельмах, Чотири 364) - Свернули к жилищу отца Бориса, который уже с полвека был тут попом (Стельмах, Четыре 300); От і з ким він буде вечеркувати... (Стельмах, Чотири 353) Вот с кем он проведёт вечер (Стельмах, Четыре 291); Ех, живем, аби день переднювати (Стельмах, Чотири 357) - Э, живём, лишь бы день дотянуть до вечера (Стельмах, Четыре 295); У цьому гиблому місці я знайшов би сухі острівці, де перше літували журавлі (Стельмах, Чотири 379) - В этом гиблом месте я нашёл бы сухие островки, куда прежде на лето прилетали журавли (Стельмах, Четыре 311).

Лакунарними виявилися й похідні дієслова інших словотвірних моделей, наприклад: $A$ ти, коли подумати, не надівочилась... (Стельмах, Чотири 535) - А ты, если подумать, не нагулялась в девках (Стельмах, Четыре 447); Роз'ярллюйте волів - та й до столу (Стельмах,

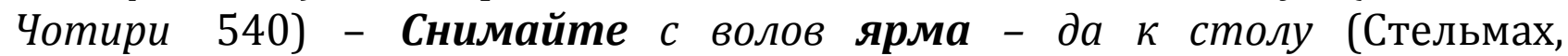
Четыре 437); Люди, не легковажте, рятуйте хлопчика, бо воно мале, дурне... (Стельмах, Чотири 557) - Люди, не проявляйте легкомыслия, спасайте мальчика... (Стельмах, Четыре 452); I птиця не склювала вишні напевне, і їі поменшало у війну (Стельмах, Чотири 475) - И птица не склевала их - наверное, и ее меньше стало в войну (Стельмах, Четыре 382); Ти очманів, чи змалів, чи твій баняк догори дном перевернувся? (Стельмах, Чотири 249) - Ты ошалел, или впал в детство, или твой чугунок вверх дном перевернулся? (Стельмах, Четыре 206); Побув би ти, розумнику, на моєму місиі - i тебе засудомило б! (Стельмах, Чотири 132) - Побыл бы ты, умник, на моём месте, и тебя бы свела судорога (Стельмах, Четыре 107); Здорожився? Їсти хочеш? (Стельмах, Чотири 128) - Устал с дороги? Кушать хочешь? (Стельмах, Чотири 104); Весніє... Саме щастя послало тебе... (Стельмах, Чотири 49) - Скоро весна. Само счастье послало тебя... (Стельмах, Чотири 39).

Ще однією причиною можливих лексичних лакун (а значить i проблемою міжкультурної комунікації) $\epsilon$ мовотворчість самого автора твору, бо оказіональні слова точно не мають жодних відповідників у мові перекладу. Доволі часто перекладач на свій смак і розсуд компенсує відсутні в російській мові лексеми кількома словами. Наприклад: $\epsilon$ у мене один дід-болотяник, який оцю мокруху настоює на вісімнадияти помічних зіллях і коріннях (Стельмах, Чотири 156) - Есть у меня один дед, болотный чёрт, который мокруху настаивает на восемнадцати полезных травах и кореньях (Стельмах, Четыре 127); Колись виорав на полі один мудригайло баняк із золотими побрязкачами (Стельмах, Чотири 11) - Давным-давно пахал поле один умник-разумник и нашёл горшок $с$ золотыми 
побрякушками (Стельмах, Четыре 8); ...Закинув гачок під стріли очерету, які й не журилися, що вже минув літопровід (Стельмах, Чотири 492) Забросил удочку под стрелы камыша, которые и не журились, что уже миновали проводы лета (Стельмах, Четыре 397); От чи буде тільки в холодині родити гречка? (Стельмах, Чотири 476) - Вот только будет ли в холодном краю родить гречиха? (Стельмах, Четыре 383); Іч, їм коржі не вгодили. Може, сластьонів заманулось? (Стельмах, Чотири 442) - Ишь, им коржи не по вкусу. Может, оладьев с мёдом захотелось? (Стельмах, Четыре 354); 3 ярмаркової колотнечі та розтічу повз вітряки виїхали в рожевий надвечірній сонщеграй... (Стельмах, Чотири 123) - Из ярмарочной сутолоки и разброда мимо ветряков выехали в розовое предвечернее солнечное марево (Стельмах, Четыре 99); Чого ти, ласкавочко? (Стельмах, Чотири 451) - Что ты, доченька? Что, маленькая? Что, ласковая? (Стельмах, Четыре 362).

Окрім оригінальних іменників, трапляються в романі «Чотири броди» й індивідуально-авторські прикметники, частина яких не отримала в перекладі однослівного відповідника. Наприклад: То для чого йому копати яму в лісах, коли можна і в льоху заховати зерно, i вшахроване, $i$ зібране по лісових галявинах? (Стельмах, Чотири 91) - Так зачем ему копать в лесах яму, если можно в подземелье запрятать зерно - $и$ добытое мошенничеством, и собранное на лесных полянах? (Стельмах, Четыре 72); Коли і по селах люди поволеньки потягнулися до книги, до них із міста приїхав хмаробровий статурний агроном (Стельмах, Чотири 9) Когда в сёлах люди помаленьку потянулись к книге, к ним из города приехал статный, со строгими бровями агроном (Стельмах, Четыре 7); Щоб усе було для незбільшовичених дядьків хитромудро, державно і по-божому (Стельмах, Чотири 362) - Чтобы всё было для не заражённых большевизмом мужиков хитромудро, державно и по-божьему (Стельмах, Четыре 299); Таку княжну чи королівну викопав, що їх тільки в музеях красуватись... Щирозлоту (Стельмах, Чотири 513) - Такую княжну или королевну откопал, что ей только в музеях красоваться... Из чистого золота (Стельмах, Четыре 414).

Турбуючись про еквівалентність перекладу на всіх рівнях і тим самим бажаючи забезпечити безпроблемний міжкультурний діалог, досвідчені перекладачі можуть вдаватися до певних замін окремих фрагментів оригіналу або до пошуку аналогів. Ці перекладацькі прийоми теж належать до кола проблем лакунології, бо в такий спосіб можна компенсувати лакуни 3 найменшими втратами. Заміни можуть мати характер конкретизації чи генералізації змісту. Так, наприклад, на першій сторінці роману читаємо: $O$ пам'ять і смуток землі, чи минулися ви? (Стельмах, Чотири 4), а в перекладі $O$ память и грусть Украины! Дано ли вам быть забытыми? (Стельмах, Четыре 3). Для перекладного твору локалізація (як просторова, так і часова) важлива від самого початку, тому компенсація лакуни топосу (земля) цілком виправдана. Наступні варіанти 
перекладу теж демонструють тенденцію відмови від прямих еквівалентів або транслітерованих реалій: Дзвони мають у собі і великодні і похоронні голоси (Стельмах, Чотири 16) - Колокола хранят в себе и праздничные, $u$ погребальные голоса (Стельмах, Четыре 13); Коли густий петрівчанський вечір упав на ліси... (Стельмах, Чотири 42) - Когда густой летний вечер упал на леса... (Стельмах, Четыре 33); Цей кінь із тих, про яких у щедрівках співалось... (Стельмах, Чотири 77) - Про таких скакунов в старых песнях поют (Стельмах, Четыре 61); Я хотів поговорити з вами, як із рідним, а ви на мене косуєте, немов на Марка Проклятого (Стельмах, Чотири 72) Давно мне охота потолковать с вами по душах, а вы коситесь на меня, как на лешего (Стельмах, Четыре 57); Такого кровопролиття, як тепер, і за ординців не було (Стельмах, Чотири 475) - Такого кровопролития, как теперь, и при татарине не было (Стельмах, Четыре 382); Якось перебудуть твої потерчата без молока (Стельмах, Чотири 581) - Какнибудь обойдутся твои некрещёные без молока (Стельмах, Четыре 472); Ось і в нашій церкві було кілька запорозьких праведників зі зброєю в руках $і$ з оселедиями на голові (Стельмах, Чотири 79) - Ведь и в нашей церкви было несколько ликов запорожиев с оружием и с чубами на голове (Стельмах, Четыре 63); Він був у Болгарії гренадером, а ти на своїй землі скоропадчиком (Стельмах, Чотири 28) - Он был в Болгарии гренадёром, а ты на своей земле карателем (Стельмах, Четыре 21); «Ой люлі, люлі», прошепотіла молодиця сльозами... (Стельмах, Чотири 27) - «Баюшкибаю», - прошептала молодица сквозь слёзы... (Стельмах, Четыре 20); Яринка випровадила з корчомки двох баляндрасників, на варті поставила милогубу палянишницю Зосю (Стельмах, Чотири 588) - Яринка выпровадила из кафе двух балагуров, оставила сторожить миловидную булочницу Зосю (Стельмах, Четыре 477).

Загалом майстерність перекладача в роботі з безеквівалентними явищами оригіналу полягає у вмілому комбінуванні різних прийомів подолання лакунарності для того, аби не втратити автентичність самого художнього твору й оптимізувати міжкультурний діалог. Наприклад: Моторошно стало Семенові в цей химерний святвечір (Стельмах, Чотири 29) - Не по себе стало Семёну в этот странный святой вечер (Стельмах, Четыре 22); Як вам, тату, повертається язик отаке говорити, та ще й в святий вечір? (Стельмах, Чотири 24) - Как у вас, батько, язык поворачивается такое говорить, да ещё в сочельник? (Стельмах, Четыре 18); Оце дочекався святого вечора! (Стельмах, Чотири 29) Дождался праздничка! (Стельмах, Четыре 22); Що ж так розтривожило його? Чи давня святвечірня зірка, чи згадка про матір... (Стельмах, Чотири 24) - Что же так растревожило его? Далёкая праздничная вечерняя звезда или воспоминание о матери (Стельмах, Четыре 18). Різноманітні перекладацькі трансформації (калькування, підбір аналога, генералізація змісту й описовий переклад) мінімізують можливі втрати і 
дозволяють читачеві з іншої лінгвокультурної спільноти насолоджуватися високохудожнім словом, не помічаючи жодних лакун.

Висновки та перспективи дослідження. Міжкультурна комунікація це пізнання інших мов і культур, яке обов'язково супроводжується відкриттям нових понять, реалій, національно-специфічних явищ, тобто всього того, що є лакунарним і в певному сенсі безеквівалентним. Але художній переклад, на відміну від оригіналу, - це завжди відкрита знакова система, яка дозволяє перекладачеві застосовувати різні способи елімінування як культурологічних, так і власне мовних лакун. Типологічна та генеалогічна близькість слов'янських мов сприяє численним транслітераціям реалій, яка може доповнюватися текстовим чи підрядковим коментарем. Досить часто спостережено описовий спосіб тлумачення безеквівалентів чи їх лексична заміна (на гіпонім, гіперонім чи аналог). Однак некомпенсовані лакуни як перекладацькі втрати неминучі навіть при подоланні розбіжностей досить схожих мовних картин світу.

\section{Список використаних джерел}

Стельмах, Михайло. Чотири броди: Роман. Київ: Дніпро, 1989.

Стельмах, Михайло. Четыре брода: Роман. Перевод Н. Андриевской. Москва: Советский писатель, 1983.

\section{Sources}

Stelmakh, Mykhailo. Chotyry brody. Kyiv: Dnipro, 1989.

Stel'mah, Mihajlo. Chetyre broda. Translated by N. Andrievskaja. Moskva: Sovetskij pisatel', 1983.

\section{Список використаної літератури}

Быкова, Гульчера. Лакунарность как категория лексической системологии. Благовещенск: ИД БГПИ, 2003.

Жайворонок, Віталій. Знаки украӥнської етнокультури: Словник-довідник. Київ: Довіра, 2006.

Зорівчак, Роксолана. Реалія i переклад. Львів: Видавництво при Львівському університеті імені I. Франка, 1989.

Колода, Світлана. «Текстові лакуни як маркери специфіки лінгвокультурної спільноти в романі А. Оза “Куфса шхора"». Східний світ, № 1, 2005, с. 115-21.

Кочерган, Михайло. Основи зіставного мовознавства. Київ: ВЦ «Академія», 2006.

Манакін, Віктор. Мова і міжкультурна комунікація. Київ: ВЦ «Академія», 2012.

Манакин, Виктор. Сопоставительная лексикология. Киев: Знання, 2004.

Марковина, Ирина, Сорокин, Юрий. Культура и текст: Введение в лакунологию. Москва: ГЭОТАР-Медиа, 2010.

Приймачок, Оксана. «Типи коментарів у перекладах Лесі Українки оповідань Івана Франка». Лінгвостилістичні студї, вип. 5, 2016, с. 171-80.

Тер-Минасова, Светлана. Язык и межкультурная коммуникация. Москва: Слово, 2000.

\section{References}

Bykova, Gul'chera. Lakunarnost' kak kategorija leksicheskoj sistemologii. Blagoveshhensk, 2003.

Zhaivoronok, Vitalii. Znaky ukrainskoi etnokultury. Kyiv: Dovira, 2006. 
Zorivchak, Roksolana. Realiia i pereklad. Lviv: Vydavnytstvo pry Lvivskomu universyteti imeni I. Franka, 1989.

Koloda, Svitlana. "Tekstovi lakuny yak markery spetsyfiky linhvokulturnoi spilnoty v romani A. Oza "Kufsa shkhora"”. The World of the Orient, № 1, 2005, pp. 115-21.

Kocherhan, Mykhailo. Osnovy zistavnoho movoznavstva. Kyiv: VTs “Akademiia”, 2006.

Manakin, Viktor. Mova i mizhkulturna komunikatsiia. Kyiv: VTs "Akademiia”, 2012.

Manakin, Viktor. Sopostavitel'naja leksikologija. Kiev: Znannja, 2004.

Markovina, Irina, Sorokin, Jurij. Kul'tura i tekst: Vvedenie v lakunologiju. Moskva: GJeOTARMedia, 2010.

Pryimachok, Oksana. “Types of Commentaries in Lesia Ukrainka's Translations of Ivan Franko's Short Stories". Linguostylistic Studies, iss. 5, 2016, pp. 171-80.

Ter-Minasova, Svetlana. Jazyk i mezhkul'turnaja kommunikacija. Moskva: Slovo, 2000.

Стаття надійшла до редколегії 26.09.2019 